\title{
Composite Analysis of the Virome and Bacteriome of HIV/HPV Co-Infected Women Reveals Proxies for Immunodeficiency
}

\author{
Juliana D. Siqueira ${ }^{1}{ }^{\circledR}$, Gislaine Curty ${ }^{1}$, Deng Xutao ${ }^{2,3}$, Cristina B. Hofer ${ }^{4}$, Elizabeth S. Machado ${ }^{5}$, \\ Héctor N. Seuánez ${ }^{6,7}$, Marcelo A. Soares ${ }^{1,7, * \mathbb{C}}$, Eric Delwart ${ }^{2,3} \mathbb{C D}^{\circ}$ and Esmeralda A. Soares ${ }^{1}$ \\ 1 Programa de Oncovirologia, Instituto Nacional de Câncer, Rio de Janeiro 20231-050, Brazil; \\ sidoju@hotmail.com (J.D.S.); gcf.science@gmail.com (G.C.); esoares@inca.gov.br (E.A.S.) \\ 2 Vitalant Research Institute, San Francisco, CA 94118, USA; xdeng@vitalant.org (D.X.); \\ delwarte@medicine.ucsf.edu (E.D.) \\ 3 Department of Laboratory Medicine, University of California San Francisco, San Francisco, CA 94143, USA \\ 4 Instituto de Ginecologia, Universidade Federal do Rio de Janeiro, Rio de Janeiro 20211-340, Brazil; \\ cbhofer@hucff.ufrj.br \\ 5 Instituto de Puericultura e Pediatria Martagão Gesteira, Universidade Federal do Rio de Janeiro, \\ Rio de Janeiro 21941-912, Brazil; emachado@infolink.com.br \\ 6 Programa de Genética, Instituto Nacional de Câncer, Rio de Janeiro 20231-050, Brazil; hseuanez@inca.gov.br \\ 7 Departamento de Genética, Universidade Federal do Rio de Janeiro, Rio de Janeiro 21944-970, Brazil \\ * Correspondence: masoares@inca.gov.br; Tel.: +55-21-3207-6591
}

Received: 25 March 2019; Accepted: 2 May 2019; Published: 7 May 2019

\begin{abstract}
The human cervical microbiome is complex, and its role in health and disease has just begun to be elucidated. In this study, 57 cervical swab samples from 19 HIV/HPV co-infected women were analyzed for both virome and bacteriome composition. Virome analysis focused on circular DNA viruses through rolling circle amplification followed by next-generation sequencing (NGS). Data were assigned to virus families and genera, and HPV types were identified. NGS data of bacterial 16S from a subset of 24 samples were assigned to operational taxonomic units and classified according to vaginal microbiome community state types (CSTs). Four viral families were found: Papillomaviridae, Anelloviridae, Genomoviridae, and Herpesviridae. Papillomavirus reads were more abundant in women with premalignant cervical lesions, which were also strongly associated with multiple $(\geq 3)$ high-risk HPV infection. Anellovirus read abundance was negatively correlated with host CD4+ T-cell counts. The bacteriome revealed the presence of CST III and CST IV, and women with $\geq 1 \%$ frequency of genomovirus or herpesvirus reads displayed an increased risk of carrying CST IV. By characterizing the composition of the cervical circular DNA viruses and the bacteriome of HIV/HPV co-infected women, we identified putative interactions between these two microorganism communities and their associations with patients' clinical characteristics, notably immunodeficiency status.
\end{abstract}

Keywords: virome; microbiome; HPV; HIV; immunodeficiency

\section{Introduction}

The human microbiome consists of a collection of microorganisms such as viruses, bacteria, and fungi that symbiotically colonize the human body. This microbiome shows different profiles in each anatomical site of the body [1-3]. In the female anogenital tract, the viral and bacterial profiles are complex and present significant interpersonal variation [1,4-6]. In healthy women's anogenital region, the Papillomaviridae is the most prevalent eukaryotic viral family [1,7]; its occurrence varies from $38 \%$ to $100 \%[1,5,7,8]$. Anelloviruses are also frequent [5,9-12], while herpesvirus, polyomavirus, and 
adenovirus are usually detected in a small number of samples [1,5,7,13,14]. Among HIV-positive women, a similar diversity of viruses is found $[4,9,15,16]$, except with a higher prevalence of papillomavirus infection [17-25].

Despite the recognized complexity of viral species in women's cervical region, little is known about its association with bacterial communities in that anatomical site. There are five well-established distinct bacterial community state types (CSTs I-V) in the cervicovaginal region, classified according to their bacterial frequency profiles [26]. CSTs I, II, III, and V show a high frequency of Lactobacillus species (L. crispatus, L. gasseri, L. iners, and L. jensenii, respectively), while CST IV shows higher bacterial diversity and a high proportion of anaerobic bacteria such as Prevotella, Dialister, Atopobium, Gardnerella, Megasphaera, and Sneathia [26,27]. Interestingly, the CST IV interaction with HPV and HIV infection was shown in different studies [28-30]. Women with CST IV exhibited high proinflammatory cytokine production and $\mathrm{CD}^{+} \mathrm{CCR}^{+}$cell recruitment to the mucosal vaginal region, increasing the risk of HIV acquisition [28,29]. Moreover, the presence of CST IV has also been associated with a higher risk of HPV infection and cervical intraepithelial neoplasia [30-34]. On the other hand, most Lactobacillus sp. dominant CSTs (I, II, III, and V) show a negative association with HIV and HPV infections [28-30,35,36]. Less is known about the association and interaction of cervicovaginal CSTs with other viruses.

Research in the microbiome dramatically improved with the advent of novel sequencing methodologies. Together, these studies have exposed the complexity of the cervical virome and bacteriome in heath and disease. This is especially important in HIV-positive individuals, since HIV/AIDS has been related with enteric and blood microbiome alterations [37,38]. In this scenario, this study aims to characterize the cervical virome and bacteriome from HIV-positive women, to explore the interaction between these two communities and relate their patterns to the patients' clinical characteristics.

\section{Materials and Methods}

\subsection{Sample Selection}

Cervical samples from 19 HIV/HPV co-infected women with multiple HPV infection were selected from a group of 140 HIV-positive women followed up between 2009-2011 through the "Program for HIV-infected Pregnant Women" in Rio de Janeiro, Brazil. These samples were assessed for HPV infection by PCR and Sanger sequencing and for risk factors for HPV infection and persistence in previous studies $[39,40]$. Patients selected for the current study had their cervical samples collected at the beginning of the second trimester of pregnancy (timepoint A), and at six (timepoint $\mathrm{B}$ ) and 12 months (timepoint $\mathrm{C}$ ) after delivery, and were positive for more than one type of HPV throughout the timepoints collected as determined by PCR and Sanger sequencing (either with multiple infections at least in one timepoint or carrying different HPV types at distinct timepoints). Therefore, a total of 57 samples were analyzed in this study. The study has been approved by the Ethics Research Committees of Universidade Federal do Rio de Janeiro (UFRJ) and of Instituto Nacional de Câncer (INCA) (reference protocols 029/08 and 142/10, respectively).

\subsection{Circular DNA Enrichment and Sequencing}

Cervical sample processing was performed as previously described [41]. Total DNA was extracted with the QIAamp DNA mini kit (QIAGEN, Valencia, CA, USA) followed by circular DNA enrichment by rolling circle amplification (RCA) with the Illustra TempliPhi Amplification kit (GE Healthcare Life Sciences, Piscataway, NJ, USA). Sequencing libraries were prepared using two nanograms of the purified RCA product and the Nextera XT DNA Sample Preparation kit (Illumina Inc., San Diego, CA, USA). Samples were indexed with distinct barcodes each and sequenced in an Illumina HiSeq 2500 platform $(2 \times 100 \mathrm{nt}$ reads). 


\subsection{Virome Data Analysis}

Reads obtained were sorted for each sample based on the dual barcodes used. Bacterial and human host reads were removed by mapping these sequences to the bacterial genomes present in the RefSeq database and the human reference genome hg19 using Bowtie 2 [42]. Duplicate reads (with identical bases from position 5 to 55 from the $5^{\prime}$ end) were identified, and only one was retained. Read nucleotides with Phred quality score $<10$ were trimmed. After this preprocessing, reads were submitted to a de novo assembly with Ensemble Assembler 1.0 [43] and assigned to the virus family and genus following a previously published methodology [44]. The contigs generated and single reads were submitted to a BLASTX [45] search against a virus protein database from RefSeq. Sequences that showed an $e$-value $<0.001$ were compared to an in-house protein database with non-viral sequences derived from GenBank's non-redundant database. Finally, the $e$-values were compared, and sequences that showed the lowest $e$-value when compared to virus protein sequences were classified into a virus family according to the most similar sequence in the database.

To avoid false-positive results, virus families with less than 50 reads were excluded from further analyses. During the removal of host reads, human endogenous retroviruses (HERV) were also discarded, since they represent greater than $8 \%$ of the human genome [46]. As most of the reads attributed to Retroviridae were HERVs, we also excluded this family from further analysis to avoid the biased underrepresentation of this virus family. We have used the normalized number of reads to each virus family in our analyses. The number of reads assigned to each virus family from the remaining viruses was normalized by calculating the $\log 10$ of 1 plus the number of reads assigned to each viral family divided by the total number of reads multiplied by one million $(\log 101+$ (number of reads assigned to each genus or viral family/total number of reads $\times 1,000,000)$ ). We have also normalized the number of reads assigned to each virus family divided by the sequences submitted to BLASTX (reads of viral origin). Finally, the proportion of reads of each virus family was also used, calculated by dividing the number of reads assigned to each virus family by the total number of sequences submitted to BLASTX.

\subsection{Papillomaviridae Identification and Diversity}

Virome reads from each sample were mapped to genomes of different HPV types with BWA [47]. Reads that mapped to multiple HPV references or regions were randomly assigned to one region/reference. The number of reads mapped to each reference was measured with SAMTOOLS [48] as described previously [41]. The percentage of reads of each HPV type was calculated as a fraction of the total reads mapped to any HPV reference genome used.

\subsection{Bacterial Community State Type (CST) Characterization}

The bacteriome analyses were performed for the postpartum samples (timepoints B and C) from 12 out of the 19 women of this study, because their bacterial 16S gene had already been sequenced in a previous study [49]. Briefly, a 724-bp fragment spanning the variable regions V3 to V6 of the bacterial 16S rRNA gene was PCR-amplified using primers 338F and 1061 [49]. The $16 \mathrm{~S}$ sequence data were reanalyzed herein to evaluate the association of bacterial CSTs with the cervical virome. Briefly, the reads from bacterial 16S rRNA sequences were assigned to operational taxonomic units (OTUs) using QIIME's closed reference script (Greengenes Database). OTUs with relative abundance lower than $0.005 \%$ were discarded, and those remaining were summarized at the species level. Unsupervised hierarchical clustering based on Bray-Curtis dissimilarity and average linkage was performed in the $R$ environment and was applied to define clusters according to the abundance and taxa diversity of each sample. The clusters found were assigned to vaginal microbiome CSTs, as defined in previous studies [26,50]. 


\subsection{Genomoviridae Complete Genomes}

Samples with reads from Genomoviridae were submitted to an assembly with reference using Geneious ${ }^{\circledR}$ v.9.1 (Biomatters, Auckland, New Zealand). The reference used for each sample was the sequence from the database that showed the best similarity score to the reads in BLASTX searches. The consensus sequences were extracted and aligned using ClustalW2 [51]. Phylogenetic analysis was performed with PhyML 3.0 [52] with the most fit evolutionary model determined by Model Generator [53].

\subsection{Assessing the Presence of Fungus in the Samples}

Since the only genomovirus with known tropism infects fungi [54], four cervical samples with reads to this viral family and six samples without reads of Genomoviridae were analyzed for the presence of fungal DNA using semi-nested PCR with ITS1/ITS4 primers in the first round and ITS86/ITS4 in the second round under previously described conditions [55], except for the enzyme used, which was Taq DNA polymerase (New England Biolabs, Ipswich, MA, USA). PCR-amplified products were detected in $1 \%$ agarose gel electrophoresis and purified with a QIAquick PCR purification kit (QIAGEN) following manufacturer's instructions. Purified products were sequenced by Sanger with the primers used in the second PCR round, and the sequences generated were assembled and edited with Geneious ${ }^{\circledR}$ v.9.1 (Biomatters). The consensus sequences were extracted and submitted to BLASTN to identify the fungi present in the samples.

\subsection{Statistical Analyses}

The frequency of reads or the normalized number of reads of each virus family was used to calculate the Spearman's correlation coefficient with the HIV viral load and CD4 ${ }^{+}$T-cell counts. The Mann-Whitney $U$ test was used to compare the difference of read distribution or normalized number of reads for all virus families between samples with distinct cytological results. The odds ratio (OR) and 95\% confidence interval values were estimated for the association of cytological lesions with multiple infections by high-risk HPV types. Similarly, the comparison of the frequency of reads or normalized number of reads of each virus family to CSTs was determined with the Mann-Whitney test. The association and risk analysis of CSTs with the presence of HPV16 was performed with the relative risk (RR) statistics. The RR was also used to analyze the association of frequency below 1\% of Anelloviridae, Genomoviridae, or Herpesviridae with CSTs. All statistical analyses were performed with SPSS (IBM Corporation, Chicago, IL, USA), and graphical representations were generated with GraphPad Prism (GraphPad Software Inc., San Diego, CA, USA) or with Microsoft Excel (Microsoft Corp., Seattle, WA, USA).

\subsection{Data Availability}

The consensus sequences obtained in this study were deposited in Genbank under the accession numbers MK513442 and MK513443. Sequencing reads were submitted to the Sequence Read Archive (SRA) under the project numbers PRJNA418043 and PRJNA392046.

\section{Results}

The 19 patients studied herein were selected from a cohort previously analyzed for HPV infection, persistence, and associated risk factors [39,40]. The average age of the patients was 28 years, and 53\% were married/co-habited with a single partner (Table 1). Eight patients were current smokers at the sample collection time or smoked previously, six had less than four lifetime sexual partners, and 10 had a previous history of sexually transmitted diseases other than HIV infection. Only four women had already been under antiretroviral therapy (ART) before conception, and all of them had been treated with combinatorial ART during pregnancy. The median CD4 ${ }^{+}$T-cell counts were 327/ $\mathrm{mm}^{3}$, and the HIV-1 viral load was 8227 copies/mL at moment of the study's enrollment (timepoint A). 
At the first, second, and third collection timepoints, nine, 14, and 10 women presented low-grade or high-grade squamous intraepithelial lesions (LSIL or HSIL), respectively. During the complete follow-up, 16 women presented LSIL or HSIL at least in one timepoint studied (Table 1).

Table 1. Demographic and clinical characteristics of the $19 \mathrm{HIV} / \mathrm{HPV}$ co-infected women studied.

\begin{tabular}{|c|c|c|}
\hline Characteristic & $n$ & $\%$ \\
\hline Average age (years; \pm SD) & $28 \pm 6$ & \\
\hline Married/co-habitating status & 10 & 53 \\
\hline Past/Present smoking & 8 & 42 \\
\hline Number of sexual partners $\geq 4$ & 13 & 68 \\
\hline Previous sexually transmitted infection & 10 & 53 \\
\hline ART initiation before conception & 4 & 21 \\
\hline Median CD4 ${ }^{+}$T-cell counts at study enrollment (cells $\left./ \mathrm{mm}^{3} ; \mathrm{IQR}_{50}\right)$ & $327(289-492)$ & \\
\hline Median HIV viral load at study enrollment (copies/mL; $\mathrm{IQR}_{50}$ ) & $8227(933-13,824)$ & \\
\hline \multicolumn{3}{|c|}{ Presence of high-grade or low-grade squamous intraepithelial lesion } \\
\hline First collection & 9 & 47 \\
\hline Second collection & 14 & 74 \\
\hline Third collection & 10 & 53 \\
\hline
\end{tabular}

ART, antiretroviral therapy; $\mathrm{IQR}_{50}$, interquartile range $50 \%$.

The average number of reads obtained per sample after trimming out the low-quality reads was 4,193,239 (931,784-18,616,732). Overall, four viral families presented more than 50 reads in the samples. The most representative was Papillomaviridae, with $86 \%$ of the reads, followed by Anelloviridae (12\%), Genomoviridae (2\%), and Herpesviridae (0.06\%). Papillomavirus reads were found in all but two of the 57 samples (44A and 44B), and reads from Genomoviridae were found in a high proportion in three samples (Figure 1). The normalized number of reads from papillomaviruses was significantly higher $(p<0.001)$ in women that presented any type of intraepithelial lesion (LSIL or HSIL) compared to women with normal or atypical squamous cells of undetermined significance (ASCUS) cytology (Figure 2A). A correlation analysis of clinical HIV-related data (available only for the first collection timepoint) to the normalized number of anellovirus reads per total reads showed a moderate but significant negative correlation with the CD4 ${ }^{+} \mathrm{T}$-cell counts of the subjects $\left(\mathrm{r}_{\mathrm{s}}=-0.499 ; p=0.03\right)$ (Figure $2 \mathrm{~B}$ ). The normalized number of anellovirus reads per viral reads showed similar significance $\left(r_{s}=-0.490\right.$; $p=0.033)$, as well as the percentage of anellovirus reads $\left(r_{\mathrm{s}}=-0.525 ; p=0.021\right)$. The association between HIV viral load and anellovirus reads was not significant in any read normalization calculated $(p=0.099, p=0.056$, and $p=0.259$, respectively).

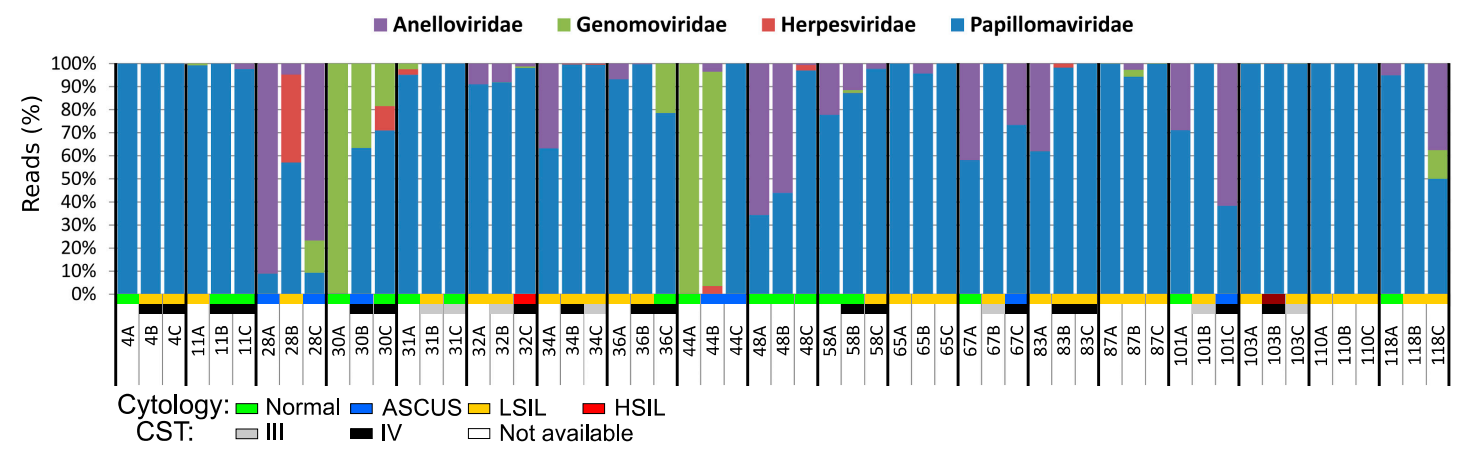

Figure 1. Distribution of the reads assigned to each virus family found in the cervical samples over time. A number was assigned to each patient studied followed by letters that represent the collection timepoints studied. The cytological results (normal, ASCUS, LSIL, or HSIL) and the CSTs of the samples are color-coded according to the graphical legend at the bottom of the Figure. A: beginning of second trimester of pregnancy; B: six months after delivery; C: twelve months after delivery; ASCUS: atypical squamous cells of undetermined significance; LSIL: low-grade squamous intraepithelial lesion; HSIL: high-grade squamous intraepithelial lesion; CST: community state type. 


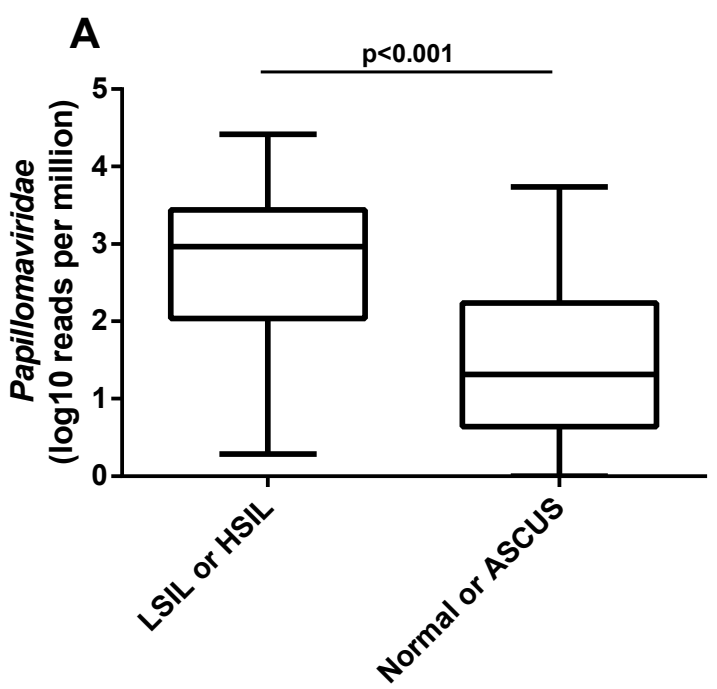

B

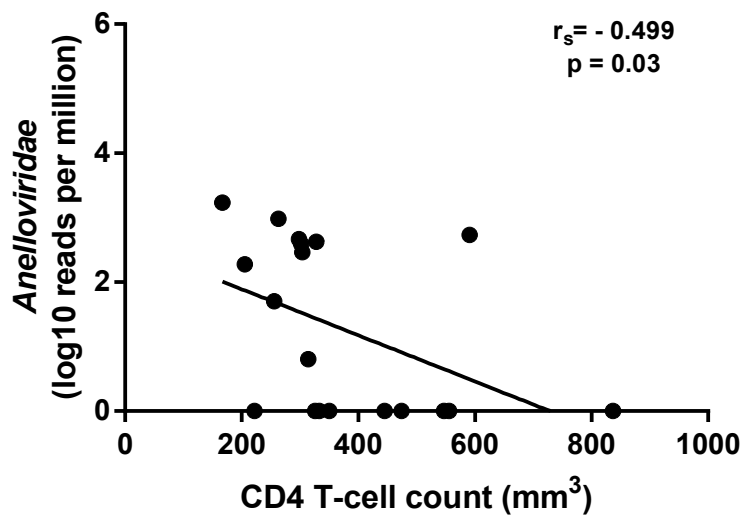

Figure 2. Clinical data and normalized number of reads from virus families. (A) Comparison of normalized number of viral reads assigned to Papillomaviridae to total number of reads between samples with normal or ASCUS (atypical squamous cells of undetermined significance) and with LSIL or HSIL (low-grade or high-grade squamous intraepithelial lesion, respectively). (B) Negative correlation between the normalized number of reads assigned to Anelloviridae to total number of reads and patients' $\mathrm{CD}^{+} \mathrm{T}$-cell counts per $\mathrm{mm}^{3}$ of blood at the time of sample collection.

Reads from two samples (30A and 87B) assembled one complete genomovirus genome each. Both genomes had the three characteristic open reading frames (replication associated protein, or Rep; RepA, and CP) and the nonamer of the stem-loop structure (Figure 3A,B). A phylogenetic analysis using the Rep amino acid sequences showed that the two viruses found were different species of the Gemykibivirus genus (Figure 3C). The gemykibivirus 30A (GmkV30A) clustered with the Human-associated gemykibivirus 1 species includes viruses isolated from human blood (acc.\# LK931485) [56], plasma (acc.\# KP974694) [57] and sewage (acc.\# KJ547644 and acc.\# KJ547645) [58]. The GmkV87B, on the other hand, clustered with the Human-associated gemykibivirus 2 species, which includes strains isolated from human cerebrospinal fluid (acc.\# KP133075, acc.\# KP133076, and acc.\# KP133077), from human feces (acc.\# KP133078 and acc.\# 1330799) and from sewage (acc.\# KP133080) [59].

The only genomovirus with a confirmed host is the Sclerotinia sclerotiorum hypovirulence-associated DNA virus 1 (SsHADV-1) that infects the plant pathogenic fungus Sclerotinia sclerotiorum [54]. Considering this and the ubiquous presence of members of the Genomoviridae family, we evaluated the presence of fungi DNA in a subset of cervicovaginal samples. Samples 30A, 31A, 44A, and 87B, presenting Genomoviridae reads, and samples 4A, 48A, 58A, 67A, 101B, and 118A, with no evidence of Genomoviridae reads (both sets chosen randomly, but including the two samples from which the complete genomes were derived), were analyzed by PCR. Candida sp. was identified in three samples (4A, 30A, and 31A), and Sarocladium sp. was identified in one sample (87B). Therefore, fungal DNA was identified in three (30A, 31A, and 87B) of four samples with Genomoviridae reads and in one of the controls. 

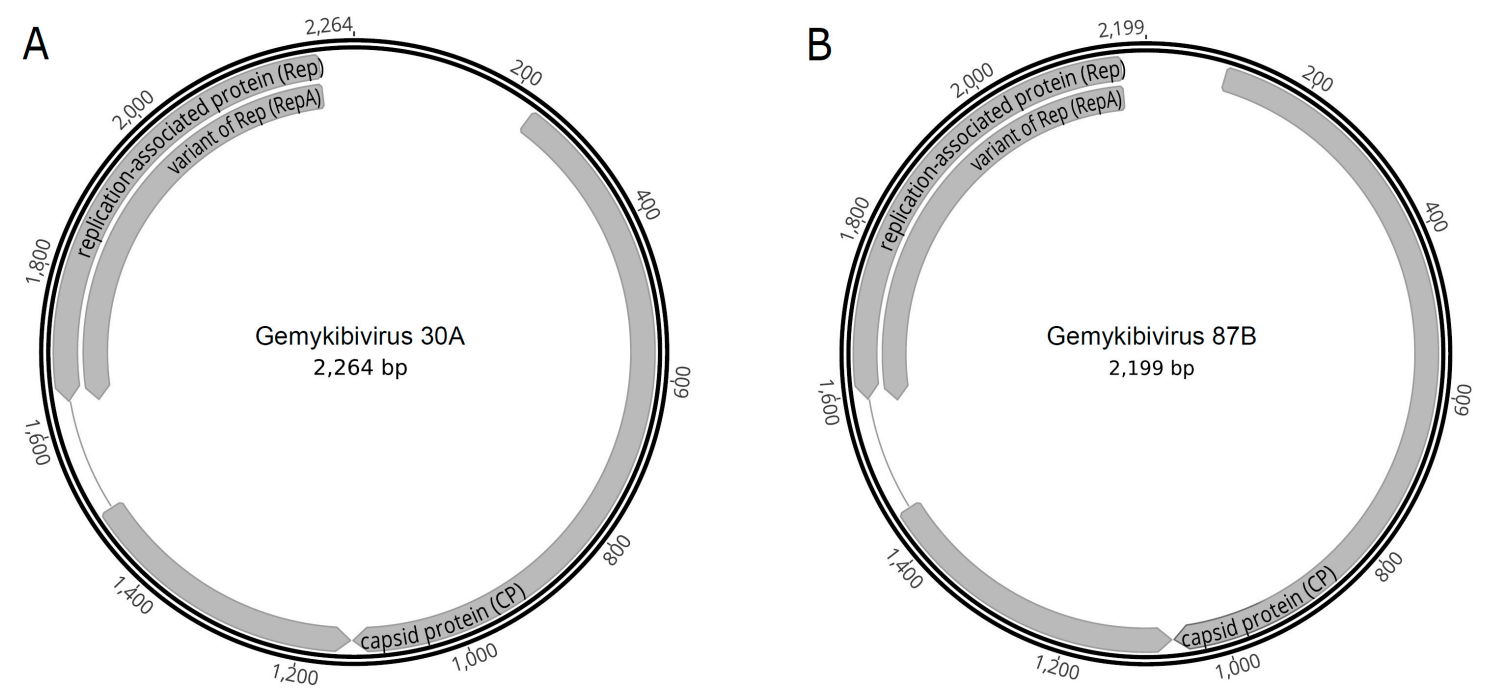

C

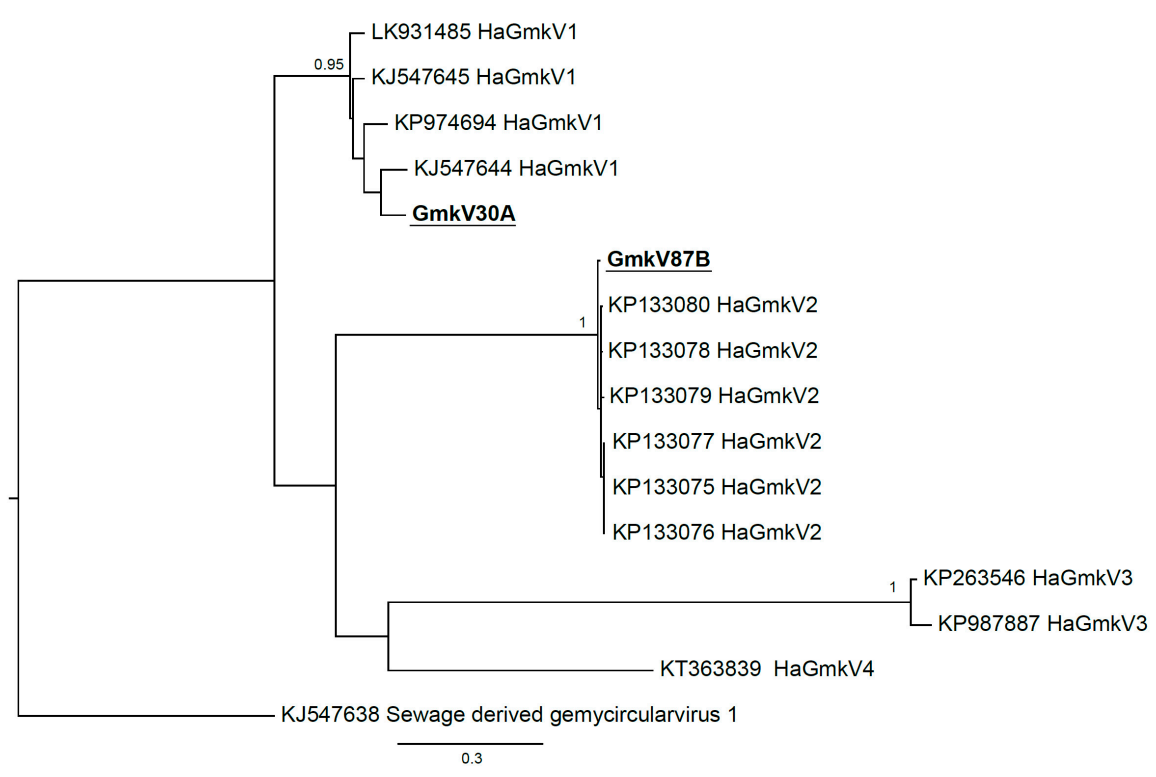

Figure 3. Human-associated gemykibivirus (HaGmkV) genome sequences and phylogenies. Genome organization of gemykibivirus 30A (A) and $87 \mathrm{~B}(\mathbf{B})$, isolated from the respective samples and collection timepoints. (C) Maximum likelihood phylogenetic tree reconstructed with amino acid sequences from the gemykibivirus replication-associated protein. Phylogenetic analysis was performed with PhyML 3.0 [52] with the evolutionary model determined by the Model Generator [53] and 1000 bootstrap replicates. Only bootstrap values above $70 \%$ are shown in the tree. Sequences assembled in this study are bolded and underlined. Sequences retrieved from Genbank are identified with their respective accession numbers.

When analyzing the reads assigned to different HPV types and assembling their genomes, we were able to identify 41 different HPV types belonging to the Alphapapillomavirus genus. Patients showed different HPV type proportion patterns among them, and there was also intrapatient HPV type variation over time (Figure 4). The most prevalent HPV type was HPV16 (present in 79\% of the patients in at least one timepoint), followed by HPV51 and HPV56 (53\% each), HPV52 (47\%), and HPV59 (37\%). Four HPV types were found in only one sample. 


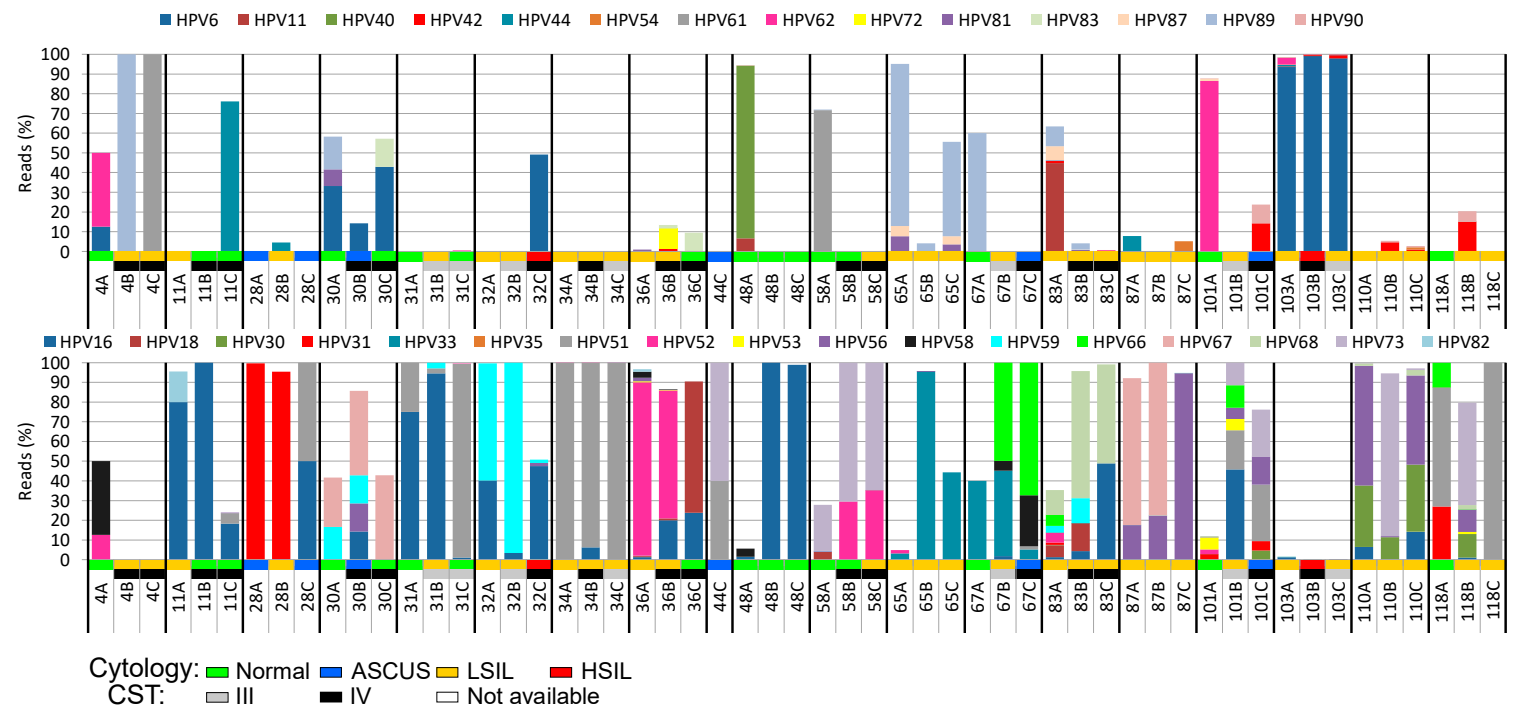

Figure 4. Cumulative distribution of reads mapped to each HPV type found in the analyzed cervical samples over time. A number was assigned to each patient studied followed by letters that represent the collection timepoints studied. The cytological results (normal, ASCUS, LSIL, or HSIL) and the CSTs of the samples are color-coded according to the graphical legend at the bottom of the figure. The upper panel depicts low-risk HPV types, while the lower panel shows the high-risk HPV types found. A: beginning of the second trimester of pregnancy; B: six months after delivery; C: 12 months after delivery; ASCUS: atypical squamous cells of undetermined significance; LSIL: low-grade squamous intraepithelial lesion; HSIL: high-grade squamous intraepithelial lesion; CST: community state type.

Reads of multiple HPV types were found in 49 (89\%) samples (Figure 4). An average of five different HPV types was found per sample, varying from one to 20 (sample 83A). More than one high-risk or probable/possible high-risk HPV (hr-HPV) types were observed in $87 \%$ of the samples. The two samples displaying HSIL (32C and 103B) had reads of multiple HPV types including HPV16 and other high-risk (hr) types (Figure 4). Multiple infections by three or more hr-HPV types were strongly associated with the presence of LSIL or HSIL (odds ratio 3.2, 95\% CI 1.1-9.7).

When different timepoints of the same patient are compared for HPV type persistence, HPV33 was found in all three follow-up samples of the two women positive for this virus type (Figure 4). HPV16 was found in 15 women, and persisted in all three timepoints in nine $(60 \%)$ of them. The HPV types that showed the greatest rates of persistence in at least two collection timepoints were HPV33 and HPV73 (100\% persistence), HPV67 (75\%), HPV16 (73\%), and HPV59 (71\%). Twelve HPV types were present in only one collection timepoint, and four of them were present only in the first collection timepoint, i.e., the second trimester of pregnancy (HPV40, $n=2$; HPV84, $n=1$; HPV86, $n=3$; HPV102, $n=2)$.

Although samples with HSIL have a variety of HPV types $(32 \mathrm{C}, n=4 ; 103 \mathrm{C}, n=12)$, most of their reads ( $>96 \%$ ) are assigned to only one (103C) or two (32C) HPV types (Figure 4). The percentage of viral reads from high-risk or probable/possible hr-HPV types was greater than those of other types in almost all the samples, regardless of cytological results (39/55 samples, 71\%).

The hierarchical clustering analysis of the bacteriome data revealed the presence of two distinct CSTs: CST III (Lactobacillus iners-dominant) and CST IV (high proportion of anaerobic bacteria). They were present in $32 \%$ and $68 \%$ of the samples, respectively (Figure 5). When samples classified with distinct CSTs were compared for the presence of HPV16 (the most frequent HPV found), those harboring CST IV displayed a higher proportion of infections without HPV16 (33\%) than those with CST III (14\%) (Figure 6), but the risk association between CST IV and HPV16 was not statistically significant $(\mathrm{RR}=0.75(0.44-1.26))$. 


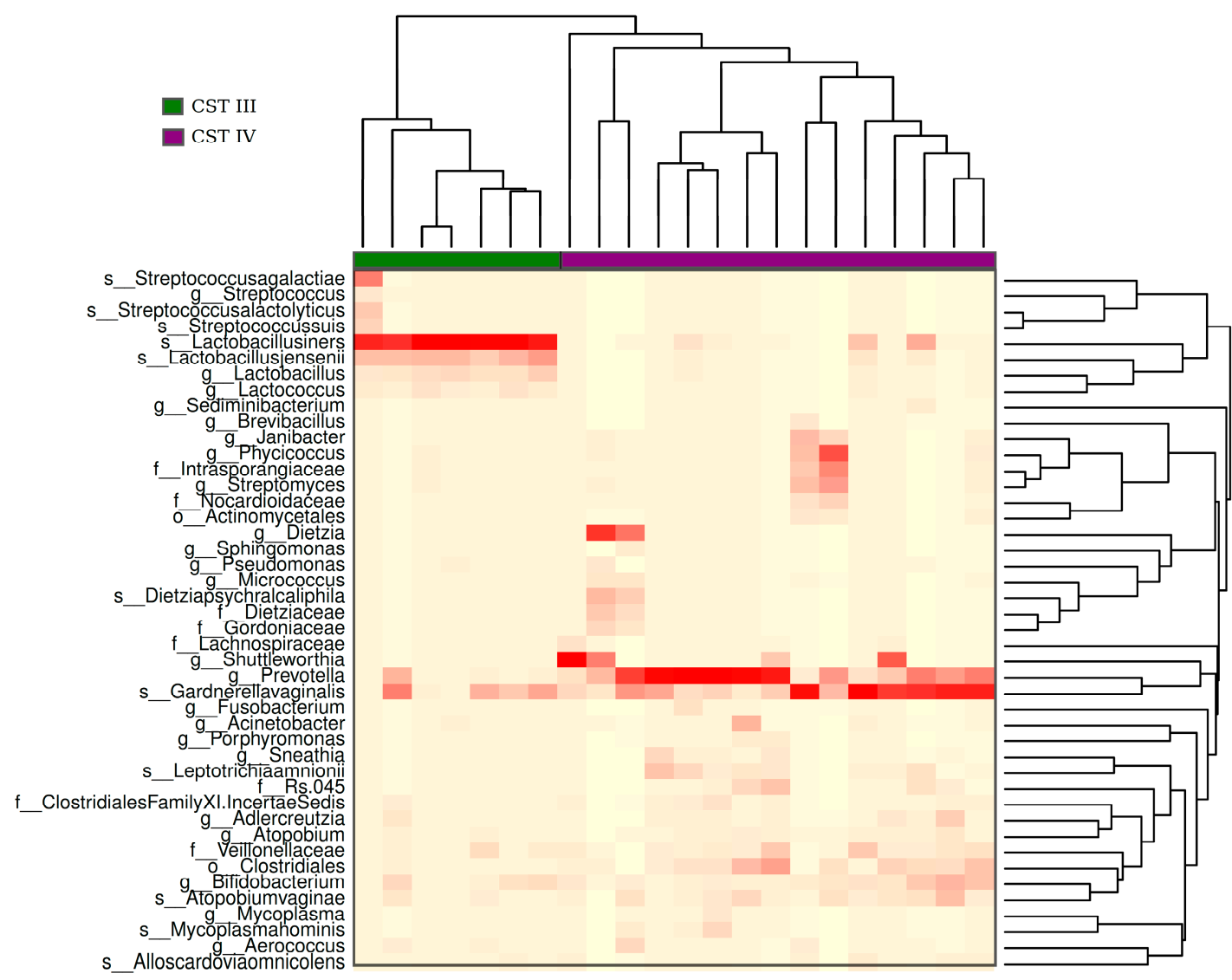

Figure 5. Heatmap of hierarchical clusterization of the bacteriome present in the analyzed samples. The heatmap shows the abundance of bacteria within the samples. The color gradient of red to white in the heatmap represents the gradient of high to low abundance of bacterial species, respectively. Based on the abundance of bacteria, samples were clustered into two groups: CST (community state type) III (green) and IV (purple). CST III exhibits a high abundance of Lactobacillus iners and CST IV shows a mix of bacterial species, with a high abundance of Prevotella and Gardenerella.

\section{CST}

III

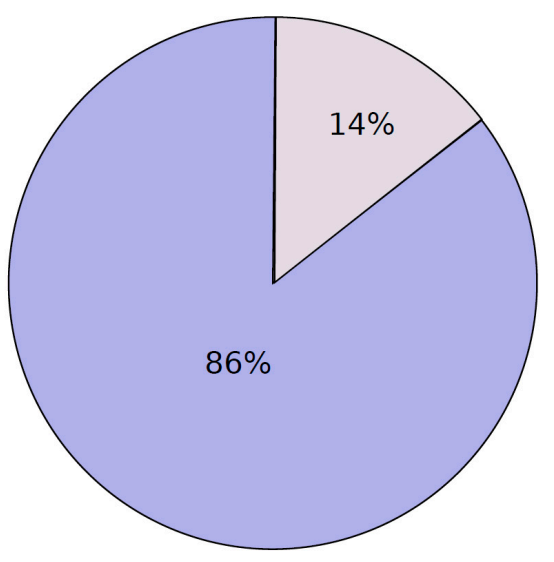

IV

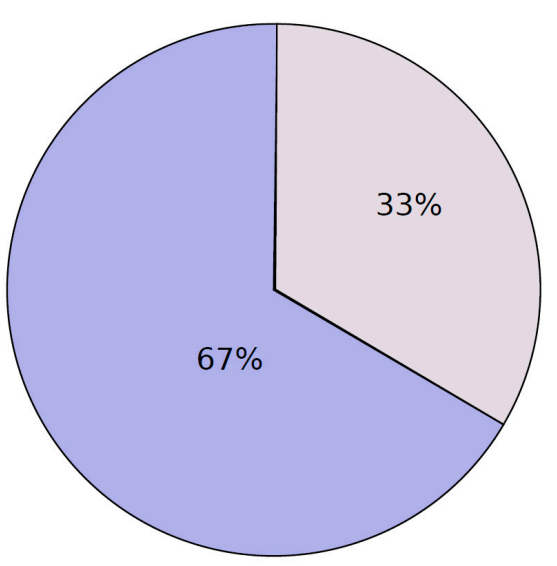

Figure 6. Proportion of patients harboring HPV-16 reads among CST III and IV cervicovaginal samples. 
We further analyzed the association of bacterial CSTs to the relative frequency or the normalized number of reads of all virus families found, except for Papillomaviridae (which was present in virtually all samples), but no significant differences were found (Figure 7A-C). However, the categorical analysis of viral frequency showed an association of genomovirus and herpesvirus with CST IV (Table 2). Women with frequency $\geq 1 \%$ of genomovirus and herpesvirus reads displayed an increased risk of carrying CST IV, (RR = 1.54 (1.11-2.12), and 1.47 (1.10-1.95), respectively).
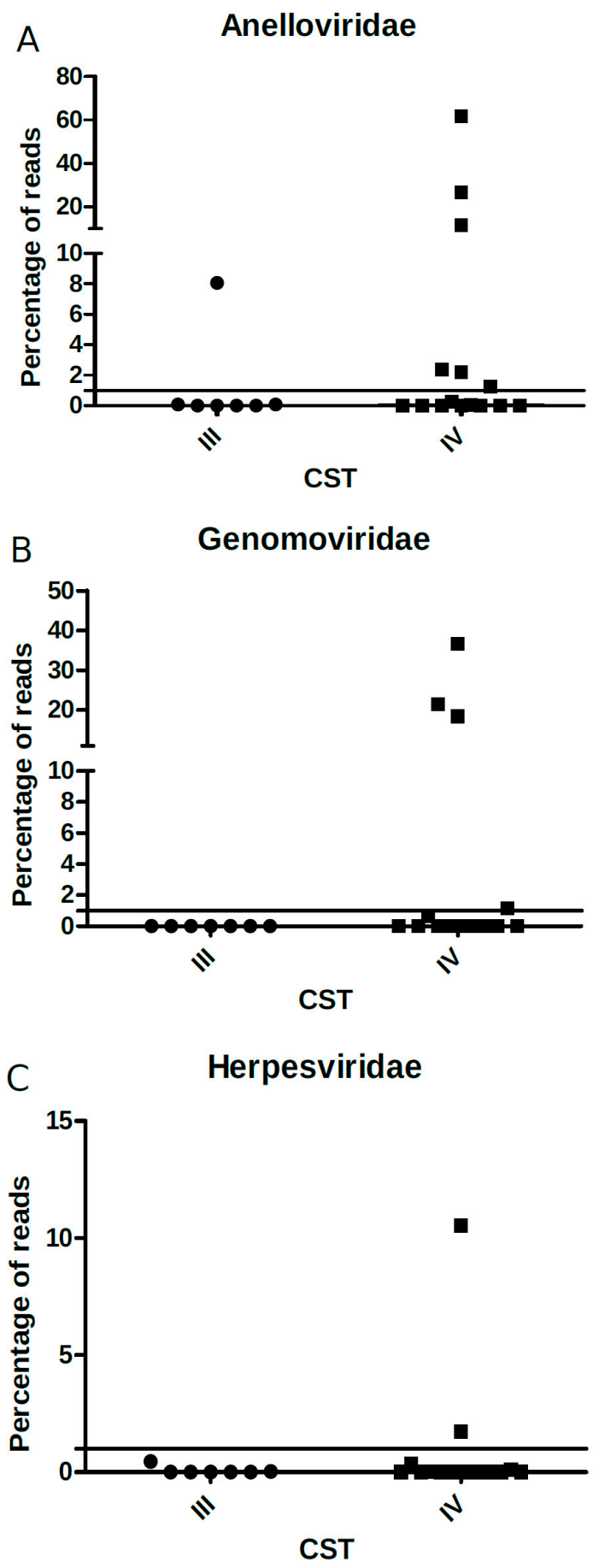

Figure 7. Percentage of (A) Anelloviridae, (B) Genomaviridae, and (C) Herpesviridae viral reads (y-axis) relative to each CST type ( $x$-axis). The solid black line depicts the proportion of $1 \%$ in the $y$-axis and each point within the graph represents one sample analyzed (circles: CST III; squares: CST IV). 
Table 2. Relative risk for CST IV associated with high read frequency $(\geq 1 \%)$ of Herpesviridae, Genomoviridae, and Anelloviridae among HIV/HPV-positive women.

\begin{tabular}{|c|c|c|c|c|c|}
\hline \multirow{2}{*}{$\begin{array}{l}\text { Virus } \\
\text { Family }\end{array}$} & \multirow{2}{*}{$\begin{array}{c}\text { Read } \\
\text { Frequency }\end{array}$} & \multicolumn{2}{|c|}{ CST \% (N/Total) } & \multirow[b]{2}{*}{ Relative Risk } & \multirow{2}{*}{$95 \%$ CI } \\
\hline & & III $(N=7)$ & IV $(N=17)$ & & \\
\hline \multirow{2}{*}{ Herpesviridae } & $<1 \%(N=22)$ & $32(7 / 22)$ & $68(15 / 22)$ & \multirow{2}{*}{1.47} & \multirow{2}{*}{$1.10-1.95$} \\
\hline & $\geq 1 \%(N=2)$ & $0(0 / 2)$ & $100(2 / 2)$ & & \\
\hline \multirow[b]{2}{*}{ Genomoviridae } & $<1 \%(N=20)$ & $35(7 / 20)$ & $65(13 / 20)$ & \multirow{2}{*}{1.54} & \multirow{2}{*}{$1.11-2.12$} \\
\hline & $\geq 1 \%(N=4)$ & $0(0 / 4)$ & $100(4 / 4)$ & & \\
\hline \multirow{2}{*}{ Anelloviridae } & $<1 \%(N=17)$ & $35(6 / 17)$ & $65(11 / 17)$ & \multirow{2}{*}{1.32} & \multirow{2}{*}{$0.83-2.10$} \\
\hline & $\geq 1 \%(N=7)$ & $14(1 / 7)$ & $86(6 / 7)$ & & \\
\hline
\end{tabular}

\section{Discussion}

The human microbiome is complex, and its role in health and disease is only beginning to be elucidated. While many recent studies have been conducted to unravel the interaction of the human virome $[1,4,7,60-62]$ and bacteriome $[3,26,32]$ with their host, the interplay between these two microbiome components is scarcely addressed. In the present study, we characterized the main DNA viruses as well the bacterial components present in the HIV-positive women's cervical region through next-generation sequencing, allowing us to address their mutual relationships. Moreover, this analysis allowed us to associate patterns of these two microorganism communities with the clinical characteristics of the patients.

The majority of viral reads found in the patients' samples analyzed herein were assigned to Papillomaviridae. This was especially true for samples of women displaying high-grade or low-grade intraepithelial lesions. Although our samples were previously selected for multiple HPV infection, unbiased cervical virome studies have found papillomaviruses as the most prevalent eukaryotic infecting virus irrespective of the genital tract health $[1,4,7,8]$. It is worth mentioning that the rolling circle amplification (RCA) method that was used favors the detection of circular DNA viruses (including anelloviruses and HPV), and may be selecting against the detection of other viruses, such as herpesviruses, which was a limitation of the current study. Besides the inter-individual diversity previously observed in cervical viromes [1], our findings also highlight the importance of HPV read counts, which could be a proxy of the HPV viral load $[4,63]$ in the presence of cervical abnormalities [64-66].

Anelloviruses are frequently found in the cervical region regardless of the presence of abnormalities [9-12,67,68]. However, they are more prevalent in HIV-positive patients [69], and viral load in the blood is higher in immunosuppressed individuals $[70,71]$ and increase with AIDS progression $[37,72]$, suggesting a negative association with the host immune response. Some studies propose the use of anellovirus viral load in blood as a marker to monitor immunologic reconstitution in immunossupressed and in HIV-positive patients $[37,71,73,74]$. Our study shows that such association between the immune response and anellovirus normalized reads or read proportion can be extended to the cervical region, showing that anellovirus read counts in this mucosa are inversely correlated with $\mathrm{CD} 4^{+} \mathrm{T}$-cell counts in the periphery.

Genomoviridae is a recently established viral family [75] that includes the only identified ssDNA virus that infects fungi [54]. More than 100 members of this viral family have been described from different isolation sources (plants, animals, and environmental) [75,76]. Human-associated gemykibiviruses have been previously described from human pericardial [77] and cerebrospinal [59,78] fluids, plasma [79,80], blood [56], feces [59], and also from sewage [9,58]. In this study, we characterized two complete genomes of this virus identified in the female genital region. Other metagenomics studies investigating cervical samples [1,4,7] did not find this viral family, which was probably because it had only recently been described in humans $[56,57,59,77,78,80]$. Even though one of the four genomovirus-positive samples analyzed in this study was negative for fungal DNA, the prevalence of 
fungal DNA-positive samples was higher among the genomovirus-positive samples (75\%) than in the negative counterparts (17\%). Novel studies evaluating genomovirus replication or seroconversion will be needed to identify the host of different genomoviruses.

Our analysis of samples previously identified as HPV-positive by Sanger sequencing failed to identify papillomavirus reads in two samples from the same patient (44A and 44B). These results may be due to the limitations of the methodology used, since RCA will amplify circular DNA, and consequently will fail to detect HPV copies integrated into the host DNA, which may be the case for those samples. Despite our limitations, we could observe a high inter-patient variability regarding the frequency and diversity of different HPV types. Concomitant infection with more than one HPV type was associated with an increased risk of cervical lesions in several studies [81-84] and with HPV persistence [85]. In our study, we found a higher risk for the presence of cervical abnormalities in women that carried at least three high-risk or probable/possible high-risk HPV types. Also in agreement with previous reports, we found a higher prevalence of HPV persistence with the high-risk HPV types [86-88]. We could not evaluate the overall risk of HPV multiple infections or the impact of HPV persistence, because our samples were selected based on the identification of more than one HPV over three collection timepoints.

The bacteriome has been recently described as a critical factor that could affect the increase or decrease of viral infections [89]. The female lower reproductive tract harbors complex communities of microorganisms that are important to maintain health and protect the cervix from viral infections. Bacterial cervix communities are clustered into five groups named community state types (CST) I to V. CSTs I, II, III, and V are predominantly formed by Lactobacillus sp. (L. crispatus, L. iners, L. gasseri, and L. jensenii, respectively). CST IV exhibits higher species diversity and a high proportion of multiple anaerobic bacteria, including Gardenerella, Prevotella, Atopobium, Sneathia, Aerococcus, and Megasphaera [26,50]. In the current study, we showed the presence of only two CSTs (III and IV) in the samples analyzed. Recent studies have shown that CSTs III and IV are associated with a higher prevalence of HIV, HPV, and HSV-2 infections [35,90]. However, little is known about the relationship of bacterial CSTs with others viral infections. We analyzed CST association for three viral families (Anelloviridae, Herpesviridae, and Genomoviridae) found in this study, which had not been previously analyzed. We observed a higher frequency of samples with read abundance $\geq 1 \%$ of Genomoviridae and Herpesviridae in CST IV, showing an increased risk of 54\% and 47\%, respectively. Additionally, CST IV samples also displayed a higher proportion of HPV non-16 viruses. The mechanisms involved in the establishment of such viral infections and how the bacteriome modulates or is modulated by them remains to be elucidated. However, our data strongly point out to a scenario in which a more immunodeficient status, which is commonly associated with CST IV, also allows the establishment of viral infections that are less frequently detected in immunocompetent hosts. This is the case of genomoviruses (associated with fungal co-infections), herpesviruses, and HPV non-16 types, as seen herein.

Despite the small number of patients followed herein, this study was able to describe the composition, dynamics, and the putative interaction of the cervical circular DNA virome and the bacteriome in a highly susceptible group of HIV-positive pregnant women. However, additional studies are necessary to clarify the role and the mechanisms of the microbiome homeostasis and its association with the host health and disease, including the development of cervical lesions and cancer.

Author Contributions: Conceptualization, M.A.S., E.D. and E.A.S.; Data curation, J.D.S., G.C., C.B.H., E.S.M. and E.D.; Formal analysis, J.D.S., G.C., D.S. and M.A.S.; Funding acquisition, E.S.M., E.D. and E.A.S.; Investigation, J.D.S., G.C. and C.B.H.; Methodology, J.D.S., G.C., D.S. and E.D.; Project administration, M.A.S., E.D. and E.A.S.; Resources, E.S.M., H.N.S., M.A.S. and E.D.; Software, D.S.; Supervision, E.A.S.; Validation, J.D.S. and G.C.; Writing—original draft, J.D.S., G.C. and M.A.S.; Writing—review \& editing, J.D.S., G.C., E.S.M., M.A.S., E.D. and E.A.S. 
Funding: This work was supported by grants of the Rio de Janeiro State Science Foundation (FAPERJ) E26/170.026/2008 and of the Brazilian Research Council (CNPq) 573806/2008-0, both under the auspice of the Brazilian Institute of Science and Technology (INCT) for Cancer Control. Additional funding was obtained from FAPERJ E25/203.571/2014 and CNPq 460346/2014-8 to E.A.S. and FAPERJ E26/111.689/2013 and CNPq 304169/2013-7 to E.S.M.

Acknowledgments: This work was part of the requirements for J.D.S. obtaining her Ph.D. degree in Oncology by the Graduate Program in Oncology of Instituto Nacional do Câncer (INCA), Brazil. J.D.S. was recipient of a "sandwich Ph.D." grant by CNPq to spend 12 months at the Blood Systems Research Institute under the supervision of E.D., where part of this work was developed.

Conflicts of Interest: The authors declare no conflict of interest.

\section{References}

1. Wylie, K.M.; Mihindukulasuriya, K.A.; Zhou, Y.; Sodergren, E.; Storch, G.A.; Weinstock, G.M. Metagenomic analysis of double-stranded DNA viruses in healthy adults. BMC Biol. 2014, 12, 71. [CrossRef] [PubMed]

2. Costello, E.K.; Lauber, C.L.; Hamady, M.; Fierer, N.; Gordon, J.I.; Knight, R. Bacterial community variation in human body habitats across space and time. Science 2009, 326, 1694-1697. [CrossRef] [PubMed]

3. Perez Perez, G.I.; Gao, Z.; Jourdain, R.; Ramirez, J.; Gany, F.; Clavaud, C.; Demaude, J.; Breton, L.; Blaser, M.J. Body Site Is a More Determinant Factor than Human Population Diversity in the Healthy Skin Microbiome. PLOS ONE 2016, 11, e0151990. [CrossRef]

4. Ameur, A.; Meiring, T.L.; Bunikis, I.; Haggqvist, S.; Lindau, C.; Lindberg, J.H.; Gustavsson, I.; Mbulawa, Z.Z.; Williamson, A.L.; Gyllensten, U. Comprehensive profiling of the vaginal microbiome in HIV positive women using massive parallel semiconductor sequencing. Sci. Rep. 2014, 4, 4398. [CrossRef] [PubMed]

5. Wylie, K.M.; Wylie, T.N.; Cahill, A.G.; Macones, G.A.; Tuuli, M.G.; Stout, M.J. The vaginal eukaryotic DNA virome and preterm birth. Am. J. Obstet. Gynecol. 2018, 219, 189.e1-189.e12. [CrossRef] [PubMed]

6. Gajer, P.; Brotman, R.M.; Bai, G.; Sakamoto, J.; Schutte, U.M.; Zhong, X.; Koenig, S.S.; Fu, L.; Ma, Z.S.; Zhou, X.; et al. Temporal dynamics of the human vaginal microbiota. Sci. Transl. Med. 2012, 4, 132ra152. [CrossRef] [PubMed]

7. Santiago-Rodriguez, T.M.; Ly, M.; Bonilla, N.; Pride, D.T. The human urine virome in association with urinary tract infections. Front. Microbiol. 2015, 6, 14. [CrossRef]

8. Ma, Y.; Madupu, R.; Karaoz, U.; Nossa, C.W.; Yang, L.; Yooseph, S.; Yachimski, P.S.; Brodie, E.L.; Nelson, K.E.; Pei, Z. Human papillomavirus community in healthy persons, defined by metagenomics analysis of human microbiome project shotgun sequencing data sets. J. Virol. 2014, 88, 4786-4797. [CrossRef]

9. Calcaterra, S.; Zaniratti, M.S.; Serraino, D.; Peroni, M.; Abbate, I.; Cappiello, G.; Piselli, P.; Pavia, C.; Rezza, G.; Ippolito, G.; et al. Cervicovaginal shedding of TT virus in HIV-infected women. J. Hum. Virol. 2001, 4, 343-345.

10. Chan, P.K.; Tam, W.H.; Yeo, W.; Cheung, J.L.; Zhong, S.; Cheng, A.F. High carriage rate of TT virus in the cervices of pregnant women. Clin. Infect. Dis. 2001, 32, 1376-1377. [CrossRef]

11. Fornai, C.; Maggi, F.; Vatteroni, M.L.; Pistello, M.; Bendinelli, M. High prevalence of TT virus (TTV) and TTV-like minivirus in cervical swabs. J. Clin. Microbiol. 2001, 39, 2022-2024. [CrossRef] [PubMed]

12. Salakova, M.; Nemecek, V.; Tachezy, R. TTV and HPV co-infection in cervical smears of patients with cervical lesions. BMC Infect. Dis. 2009, 9, 118. [CrossRef] [PubMed]

13. Berntsson, M.; Dubicanac, L.; Tunback, P.; Ellstrom, A.; Lowhagen, G.B.; Bergstrom, T. Frequent detection of cytomegalovirus and Epstein-Barr virus in cervical secretions from healthy young women. Acta Obstet. Gynecol. Scand. 2013, 92, 706-710. [CrossRef]

14. Swenson, P.D.; Lowens, M.S.; Celum, C.L.; Hierholzer, J.C. Adenovirus types 2, 8, and 37 associated with genital infections in patients attending a sexually transmitted disease clinic. J. Clin. Microbiol. 1995, 33, 2728-2731. [PubMed]

15. Oliveira, L.H.; Santos, L.S.; Nogueira, F.G. Epstein Barr virus detection in cervical samples of women living with human immunodeficiency virus. Rev. Inst. Med. Trop. Sao Paulo 2011, 53, 231-234. [CrossRef]

16. Echavarria, M.; Forman, M.; Ticehurst, J.; Dumler, J.S.; Charache, P. PCR method for detection of adenovirus in urine of healthy and human immunodeficiency virus-infected individuals. J. Clin. Microbiol. 1998, $36,3323-3326$. 
17. Campos, R.R.; Melo, V.H.; Castilho, D.M.; Nogueira, C.P.F. Prevalence of human papillomavirus and its genotypes in the uterine cervix of HIV-infected and non-infected women. Rev. Bras. Ginecol. Obstet. 2005, $27,248-256$.

18. Garbuglia, A.R.; Piselli, P.; Lapa, D.; Sias, C.; Del Nonno, F.; Baiocchini, A.; Cimaglia, C.; Agresta, A.; Capobianchi, M.R. Frequency and multiplicity of human papillomavirus infection in HIV-1 positive women in Italy. J. Clin. Virol. 2012, 54, 141-146. [CrossRef]

19. Goncalves, M.A.; Massad, E.; Burattini, M.N.; Villa, L.L. Relationship between human papillomavirus (HPV) genotyping and genital neoplasia in HIV-positive patients of Santos City, Sao Paulo, Brazil. Int. J. Std. AIDS 1999, 10, 803-807. [CrossRef]

20. Leibenson, L.; Banani, S.; Borer, A.; Meirovitz, M.; Avni, Y.S.; Singer, D.; Schlaeffer, F.; Leibenson, M.; Silberstein, T.; Wiznitzer, A.; et al. The prevalence of human papillomavirus and cervical cytology abnormalities in women infected with human immunodeficiency virus in southern Israel. Isr. Med. Assoc. J. 2011, 13, 34-38.

21. Levi, J.E.; Fernandes, S.; Tateno, A.F.; Motta, E.; Lima, L.P.; Eluf-Neto, J.; Pannuti, C.S. Presence of multiple human papillomavirus types in cervical samples from HIV-infected women. Gynecol. Oncol. 2004, 92, 225-231. [CrossRef]

22. Levi, J.E.; Kleter, B.; Quint, W.G.; Fink, M.C.; Canto, C.L.; Matsubara, R.; Linhares, I.; Segurado, A.; Vanderborght, B.; Neto, J.E.; et al. High prevalence of human papillomavirus (HPV) infections and high frequency of multiple HPV genotypes in human immunodeficiency virus-infected women in Brazil. J. Clin. Microbiol. 2002, 40, 3341-3345. [CrossRef]

23. Lima, M.D.; Braz-Silva, P.H.; Pereira, S.M.; Riera, C.; Coelho, A.C.; Gallottini, M. Oral and cervical HPV infection in HIV-positive and HIV-negative women attending a sexual health clinic in Sao Paulo, Brazil. Int. J. Gynaecol. Obstet. 2014, 126, 33-36. [CrossRef]

24. Ceccato Junior, B.P.; Guimaraes, M.D.; Lopes, A.P.; Nascimento, L.F.; Novaes, L.M.; Del Castillo, D.M.; Melo, V.H. Incidence of Cervical Human Papillomavirus and Cervical Intraepithelial Neoplasia in Women with Positive and Negative HIV Status. Rev. Bras. Ginecol. Obstet. 2016, 38, 231-238. [CrossRef]

25. Madeddu, G.; Mameli, G.; Capobianco, G.; Babudieri, S.; Maida, I.; Bagella, P.; Rocca, G.; Cherchi, P.L.; Sechi, L.A.; Zanetti, S.; et al. HPV infection in HIV-positive females: The need for cervical cancer screening including HPV-DNA detection despite successful HAART. Eur. Rev. Med. Pharmacol. Sci. 2014, 18, 1277-1285.

26. Ravel, J.; Gajer, P.; Abdo, Z.; Schneider, G.M.; Koenig, S.S.; McCulle, S.L.; Karlebach, S.; Gorle, R.; Russell, J.; Tacket, C.O.; et al. Vaginal microbiome of reproductive-age women. Proc. Natl. Acad. Sci. USA 2011, 108, 4680-4687. [CrossRef]

27. Forney, L.J.; Ravel, J. Microbial Ecology in States of Health and Disease: Workshop Summary; The National Academies Press: Washington, DC, USA, 2014; pp. 292-323.

28. Gosmann, C.; Anahtar, M.N.; Handley, S.A.; Farcasanu, M.; Abu-Ali, G.; Bowman, B.A.; Padavattan, N.; Desai, C.; Droit, L.; Moodley, A.; et al. Lactobacillus-Deficient Cervicovaginal Bacterial Communities Are Associated with Increased HIV Acquisition in Young South African Women. Immunity 2017, 46, $29-37$. [CrossRef]

29. Anahtar, M.N.; Byrne, E.H.; Doherty, K.E.; Bowman, B.A.; Yamamoto, H.S.; Soumillon, M.; Padavattan, N.; Ismail, N.; Moodley, A.; Sabatini, M.E.; et al. Cervicovaginal bacteria are a major modulator of host inflammatory responses in the female genital tract. Immunity 2015, 42, 965-976. [CrossRef]

30. Mitra, A.; MacIntyre, D.A.; Marchesi, J.R.; Lee, Y.S.; Bennett, P.R.; Kyrgiou, M. The vaginal microbiota, human papillomavirus infection and cervical intraepithelial neoplasia: What do we know and where are we going next? Microbiome 2016, 4, 58. [CrossRef]

31. Oh, H.Y.; Kim, B.S.; Seo, S.S.; Kong, J.S.; Lee, J.K.; Park, S.Y.; Hong, K.M.; Kim, H.K.; Kim, M.K. The association of uterine cervical microbiota with an increased risk for cervical intraepithelial neoplasia in Korea. Clin. Microbiol. Infect. 2015, 21, e671-e679. [CrossRef]

32. Mitra, A.; MacIntyre, D.A.; Lee, Y.S.; Smith, A.; Marchesi, J.R.; Lehne, B.; Bhatia, R.; Lyons, D.; Paraskevaidis, E.; Li, J.V.; et al. Cervical intraepithelial neoplasia disease progression is associated with increased vaginal microbiome diversity. Sci. Rep. 2015, 5, 16865. [CrossRef] [PubMed] 
33. Audirac-Chalifour, A.; Torres-Poveda, K.; Bahena-Roman, M.; Tellez-Sosa, J.; Martinez-Barnetche, J.; Cortina-Ceballos, B.; Lopez-Estrada, G.; Delgado-Romero, K.; Burguete-Garcia, A.I.; Cantu, D.; et al. Cervical Microbiome and Cytokine Profile at Various Stages of Cervical Cancer: A Pilot Study. PLoS ONE 2016, 11, e0153274. [CrossRef] [PubMed]

34. Lee, J.E.; Lee, S.; Lee, H.; Song, Y.M.; Lee, K.; Han, M.J.; Sung, J.; Ko, G. Association of the vaginal microbiota with human papillomavirus infection in a Korean twin cohort. PLoS ONE 2013, 8, e63514. [CrossRef]

35. Borgdorff, H.; Tsivtsivadze, E.; Verhelst, R.; Marzorati, M.; Jurriaans, S.; Ndayisaba, G.F.; Schuren, F.H.; van de Wijgert, J.H. Lactobacillus-dominated cervicovaginal microbiota associated with reduced HIV/STI prevalence and genital HIV viral load in African women. ISME J. 2014, 8, 1781-1793. [CrossRef]

36. Brotman, R.M.; Shardell, M.D.; Gajer, P.; Tracy, J.K.; Zenilman, J.M.; Ravel, J.; Gravitt, P.E. Interplay between the temporal dynamics of the vaginal microbiota and human papillomavirus detection. J. Infect. Dis. 2014, 210, 1723-1733. [CrossRef]

37. Li, L.; Deng, X.; Linsuwanon, P.; Bangsberg, D.; Bwana, M.B.; Hunt, P.; Martin, J.N.; Deeks, S.G.; Delwart, E. AIDS alters the commensal plasma virome. J. Virol. 2013, 87, 10912-10915. [CrossRef] [PubMed]

38. Monaco, C.L.; Gootenberg, D.B.; Zhao, G.; Handley, S.A.; Ghebremichael, M.S.; Lim, E.S.; Lankowski, A.; Baldridge, M.T.; Wilen, C.B.; Flagg, M.; et al. Altered Virome and Bacterial Microbiome in Human Immunodeficiency Virus-Associated Acquired Immunodeficiency Syndrome. Cell Host Microbe 2016, 19, 311-322. [CrossRef]

39. Meyrelles, A.R.; Siqueira, J.D.; Hofer, C.B.; Costa, T.P.; Azevedo, A.P.; Guimaraes, B.V.; Seuanez, H.N.; Soares, M.A.; Almeida, G.; Soares, E.A.; et al. HIV/HPV co-infection during pregnancy in southeastern Brazil: Prevalence, HPV types, cytological abnormalities and risk factors. Gynecol. Oncol. 2013, 128, 107-112. [CrossRef]

40. Meyrelles, A.R.; Siqueira, J.D.; Santos, P.P.; Hofer, C.B.; Luiz, R.R.; Seuanez, H.N.; Almeida, G.; Soares, M.A.; Soares, E.A.; Machado, E.S. Bonafide, type-specific human papillomavirus persistence among HIV-positive pregnant women: Predictive value for cytological abnormalities, a longitudinal cohort study. Memorias Inst. Oswaldo Cruz 2016, 111, 120-127. [CrossRef]

41. Siqueira, J.D.; Alves, B.M.; Prellwitz, I.M.; Furtado, C.; Meyrelles, A.R.; Machado, E.S.; Seuanez, H.N.; Soares, M.A.; Soares, E.A. Identification of novel human papillomavirus lineages and sublineages in HIV/HPV-coinfected pregnant women by next-generation sequencing. Virology 2016, 493, 202-208. [CrossRef]

42. Langmead, B.; Salzberg, S.L. Fast gapped-read alignment with Bowtie 2. Nat. Methods 2012, 9, 357-359. [CrossRef] [PubMed]

43. Deng, X.; Naccache, S.N.; Ng, T.; Federman, S.; Li, L.; Chiu, C.Y.; Delwart, E.L. An ensemble strategy that significantly improves de novo assembly of microbial genomes from metagenomic next-generation sequencing data. Nucleic Acids Res. 2015, 43, e46. [CrossRef] [PubMed]

44. Siqueira, J.D.; Ng, T.F.; Miller, M.; Li, L.; Deng, X.; Dodd, E.; Batac, F.; Delwart, E. Endemic Infection of Stranded Southern Sea Otters (Enhydra Lutris Nereis) with Novel Parvovirus, Polyomavirus, and Adenovirus. J. Wildl. Dis. 2017, 53, 532-542. [CrossRef]

45. Camacho, C.; Coulouris, G.; Avagyan, V.; Ma, N.; Papadopoulos, J.; Bealer, K.; Madden, T.L. BLAST+: Architecture and applications. BMC Bioinf. 2009, 10, 421. [CrossRef] [PubMed]

46. Lander, E.S.; Linton, L.M.; Birren, B.; Nusbaum, C.; Zody, M.C.; Baldwin, J.; Devon, K.; Dewar, K.; Doyle, M.; FitzHugh, W.; et al. Initial sequencing and analysis of the human genome. Nature 2001, 409, 860-921. [CrossRef] [PubMed]

47. Li, H.; Durbin, R. Fast and accurate short read alignment with Burrows-Wheeler transform. Bioinformatics 2009, 25, 1754-1760. [CrossRef] [PubMed]

48. Li, H.; Handsaker, B.; Wysoker, A.; Fennell, T.; Ruan, J.; Homer, N.; Marth, G.; Abecasis, G.; Durbin, R.; 1000 Genome Project Data Processing Subgroup. The Sequence Alignment/Map format and SAMtools. Bioinformatics 2009, 25, 2078-2079. [CrossRef] [PubMed]

49. Curty, G.; Costa, R.L.; Siqueira, J.D.; Meyrelles, A.I.; Machado, E.S.; Soares, E.A.; Soares, M.A. Analysis of the cervical microbiome and potential biomarkers from postpartum HIV-positive women displaying cervical intraepithelial lesions. Sci. Rep. 2017, 7, 17364. [CrossRef]

50. Kyrgiou, M.; Mitra, A.; Moscicki, A.B. Does the vaginal microbiota play a role in the development of cervical cancer? Transl. Res. 2017, 179, 168-182. [CrossRef] 
51. Larkin, M.A.; Blackshields, G.; Brown, N.P.; Chenna, R.; McGettigan, P.A.; McWilliam, H.; Valentin, F.; Wallace, I.M.; Wilm, A.; Lopez, R.; et al. Clustal W and Clustal X version 2.0. Bioinformatics 2007, 23, 2947-2948. [CrossRef]

52. Guindon, S.; Dufayard, J.F.; Lefort, V.; Anisimova, M.; Hordijk, W.; Gascuel, O. New algorithms and methods to estimate maximum-likelihood phylogenies: Assessing the performance of PhyML 3.0. Syst. Biol. 2010, 59, 307-321. [CrossRef]

53. Keane, T.M.; Creevey, C.J.; Pentony, M.M.; Naughton, T.J.; McLnerney, J.O. Assessment of methods for amino acid matrix selection and their use on empirical data shows that ad hoc assumptions for choice of matrix are not justified. BMC Evol. Biol. 2006, 6, 29. [CrossRef]

54. Yu, X.; Li, B.; Fu, Y.; Jiang, D.; Ghabrial, S.A.; Li, G.; Peng, Y.; Xie, J.; Cheng, J.; Huang, J.; et al. A geminivirus-related DNA mycovirus that confers hypovirulence to a plant pathogenic fungus. Proc. Natl. Acad. Sci. USA 2010, 107, 8387-8392. [CrossRef]

55. Ferrer, C.; Colom, F.; Frases, S.; Mulet, E.; Abad, J.L.; Alio, J.L. Detection and identification of fungal pathogens by PCR and by ITS2 and 5.8S ribosomal DNA typing in ocular infections. J. Clin. Microbiol. 2001, 39, 2873-2879. [CrossRef]

56. Lamberto, I.; Gunst, K.; Muller, H.; Zur Hausen, H.; de Villiers, E.M. Mycovirus-like DNA virus sequences from cattle serum and human brain and serum samples from multiple sclerosis patients. Genome Announc. 2014, 2. [CrossRef]

57. Zhang, W.; Li, L.; Deng, X.; Blumel, J.; Nubling, C.M.; Hunfeld, A.; Baylis, S.A.; Delwart, E. Viral nucleic acids in human plasma pools. Transfusion 2016, 56, 2248-2255. [CrossRef] [PubMed]

58. Kraberger, S.; Arguello-Astorga, G.R.; Greenfield, L.G.; Galilee, C.; Law, D.; Martin, D.P.; Varsani, A. Characterisation of a diverse range of circular replication-associated protein encoding DNA viruses recovered from a sewage treatment oxidation pond. Infect. Genet. Evol. 2015, 31, 73-86. [CrossRef]

59. Phan, T.G.; Mori, D.; Deng, X.; Rajindrajith, S.; Ranawaka, U.; Fan Ng, T.F.; Bucardo-Rivera, F.; Orlandi, P.; Ahmed, K.; Delwart, E. Small circular single stranded DNA viral genomes in unexplained cases of human encephalitis, diarrhea, and in untreated sewage. Virology 2015, 482, 98-104. [CrossRef] [PubMed]

60. Bukowska-Osko, I.; Perlejewski, K.; Nakamura, S.; Motooka, D.; Stokowy, T.; Kosinska, J.; Popiel, M.; Ploski, R.; Horban, A.; Lipowski, D.; et al. Sensitivity of Next-Generation Sequencing Metagenomic Analysis for Detection of RNA and DNA Viruses in Cerebrospinal Fluid: The Confounding Effect of Background Contamination. Adv. Exp. Med. Biol. 2017, 944, 53-62. [CrossRef]

61. Tirosh, O.; Conlan, S.; Deming, C.; Lee-Lin, S.Q.; Huang, X.; Program, N.C.S.; Su, H.C.; Freeman, A.F.; Segre, J.A.; Kong, H.H. Expanded skin virome in DOCK8-deficient patients. Nat. Med. 2018, 24, 1815-1821. [CrossRef] [PubMed]

62. Bal, A.; Sarkozy, C.; Josset, L.; Cheynet, V.; Oriol, G.; Becker, J.; Vilchez, G.; Sesques, P.; Mallet, F.; Pachot, A.; et al. Metagenomic Next-Generation Sequencing Reveals Individual Composition and Dynamics of Anelloviruses during Autologous Stem Cell Transplant Recipient Management. Viruses 2018, 10, 633. [CrossRef] [PubMed]

63. Thorburn, F.; Bennett, S.; Modha, S.; Murdoch, D.; Gunson, R.; Murcia, P.R. The use of next generation sequencing in the diagnosis and typing of respiratory infections. J. Clin. Virol. 2015, 69, 96-100. [CrossRef] [PubMed]

64. Heard, I.; Tassie, J.M.; Schmitz, V.; Mandelbrot, L.; Kazatchkine, M.D.; Orth, G. Increased risk of cervical disease among human immunodeficiency virus-infected women with severe immunosuppression and high human papillomavirus load(1). Obstet. Gynecol. 2000, 96, 403-409. [CrossRef] [PubMed]

65. Del Rio-Ospina, L.; Soto-De Leon, S.C.; Camargo, M.; Moreno-Perez, D.A.; Sanchez, R.; Perez-Prados, A.; Patarroyo, M.E.; Patarroyo, M.A. The DNA load of six high-risk human papillomavirus types and its association with cervical lesions. BMC Cancer 2015, 15, 100. [CrossRef]

66. Luo, H.; Belinson, J.L.; Du, H.; Liu, Z.; Zhang, L.; Wang, C.; Qu, X.; Pretorius, R.G.; Wu, R. Evaluation of Viral Load as a Triage Strategy With Primary High-Risk Human Papillomavirus Cervical Cancer Screening. J. Low Genit. Tract Dis. 2017, 21, 12-16. [CrossRef] [PubMed]

67. Salmanizadeh, S.; Bouzari, M.; Talebi, A. Detection of torque teno midi virus/small anellovirus (TTMDV/SAV) in chronic cervicitis and cervical tumors in Isfahan, Iran. Arch. Virol. 2012, 157, 291-295. [CrossRef]

68. Changani, L.; Bouzari, M.; Talebi, A. Torque teno mini virus infection in chronic cervicitis and cervical tumors in Isfahan, Iran. Intervirology 2013, 56, 265-270. [CrossRef] [PubMed] 
69. Christensen, J.K.; Eugen-Olsen, J.; Sørensen, S.L.; Ullum, H.; Gjedde, S.B.; Pedersen, B.K.; Nielsen, J.O.; Krogsgaard, K. Prevalence and prognostic significance of infection with TT virus in patients infected with human immunodeficiency virus. J. Infect. Dis. 2000, 181, 1796-1799. [CrossRef] [PubMed]

70. Touinssi, M.; Gallian, P.; Biagini, P.; Attoui, H.; Vialettes, B.; Berland, Y.; Tamalet, C.; Dhiver, C.; Ravaux, I.; De Micco, P.; et al. TT virus infection: Prevalence of elevated viraemia and arguments for the immune control of viral load. J. Clin. Virol. 2001, 21, 135-141. [CrossRef]

71. Focosi, D.; Maggi, F.; Albani, M.; Macera, L.; Ricci, V.; Gragnani, S.; Di Beo, S.; Ghimenti, M.; Antonelli, G.; Bendinelli, M.; et al. Torquetenovirus viremia kinetics after autologous stem cell transplantation are predictable and may serve as a surrogate marker of functional immune reconstitution. J. Clin. Virol. 2010, 47, 189-192. [CrossRef]

72. Thom, K.; Petrik, J. Progression towards AIDS leads to increased Torque teno virus and Torque teno minivirus titers in tissues of HIV infected individuals. J. Med. Virol. 2007, 79, 1-7. [CrossRef] [PubMed]

73. Madsen, C.D.; Eugen-Olsen, J.; Kirk, O.; Parner, J.; Kaae Christensen, J.; Brasholt, M.S.; Ole Nielsen, J.; Krogsgaard, K. TTV viral load as a marker for immune reconstitution after initiation of HAART in HIV-infected patients. HIV Clin. Trials 2002, 3, 287-295. [CrossRef]

74. Tyagi, A.K.; Pradier, A.; Baumer, O.; Uppugunduri, C.R.; Huezo-Diaz, P.; Posfay-Barbe, K.M.; Roosnek, E.; Ansari, M. Validation of SYBR Green based quantification assay for the detection of human Torque Teno virus titers from plasma. Virol. J. 2013, 10, 191. [CrossRef] [PubMed]

75. Krupovic, M.; Ghabrial, S.A.; Jiang, D.; Varsani, A. Genomoviridae: A new family of widespread single-stranded DNA viruses. Arch. Virol. 2016, 161, 2633-2643. [CrossRef]

76. Varsani, A.; Krupovic, M. Sequence-based taxonomic framework for the classification of uncultured single-stranded DNA viruses of the family Genomoviridae. Virus Evol. 2017, 3, vew037. [CrossRef]

77. Halary, S.; Duraisamy, R.; Fancello, L.; Monteil-Bouchard, S.; Jardot, P.; Biagini, P.; Gouriet, F.; Raoult, D.; Desnues, C. Novel Single-Stranded DNA Circular Viruses in Pericardial Fluid of Patient with Recurrent Pericarditis. Emerg. Infect. Dis. 2016, 22, 1839-1841. [CrossRef]

78. Zhou, C.; Zhang, S.; Gong, Q.; Hao, A. A novel gemycircularvirus in an unexplained case of child encephalitis. Virol. J. 2015, 12, 197. [CrossRef] [PubMed]

79. Zhang, C.; Park, J.S.; Grce, M.; Hibbitts, S.; Palefsky, J.M.; Konno, R.; Smith-McCune, K.K.; Giovannelli, L.; Chu, T.Y.; Picconi, M.A.; et al. Geographical Distribution and Risk Association of Human Papillomavirus Genotype 52-Variant Lineages. J. Infect. Dis. 2014, 210, 1600-1604. [CrossRef]

80. Uch, R.; Fournier, P.E.; Robert, C.; Blanc-Tailleur, C.; Galicher, V.; Barre, R.; Jordier, F.; de Micco, P.; Raoult, D.; Biagini, P. Divergent Gemycircularvirus in HIV-Positive Blood, France. Emerg. Infect. Dis. 2015, 21, 2096-2098. [CrossRef]

81. Fife, K.H.; Cramer, H.M.; Schroeder, J.M.; Brown, D.R. Detection of multiple human papillomavirus types in the lower genital tract correlates with cervical dysplasia. J. Med. Virol. 2001, 64, 550-559. [CrossRef]

82. Trottier, H.; Mahmud, S.; Costa, M.C.; Sobrinho, J.P.; Duarte-Franco, E.; Rohan, T.E.; Ferenczy, A.; Villa, L.L.; Franco, E.L. Human papillomavirus infections with multiple types and risk of cervical neoplasia. Cancer Epidemiol. Biomark. Prev. 2006, 15, 1274-1280. [CrossRef] [PubMed]

83. Castilho, J.L.; Levi, J.E.; Luz, P.M.; Cambou, M.C.; Vanni, T.; de Andrade, A.; Derrico, M.; Veloso, V.G.; Grinsztejn, B.; Friedman, R.K. A cross-sectional study of high-risk human papillomavirus clustering and cervical outcomes in HIV-infected women in Rio de Janeiro, Brazil. BMC Cancer 2015, 15, 478. [CrossRef] [PubMed]

84. Adler, D.H.; Wallace, M.; Bennie, T.; Abar, B.; Meiring, T.L.; Williamson, A.L.; Bekker, L.G. Cumulative Impact of HIV and Multiple Concurrent Human Papillomavirus Infections on the Risk of Cervical Dysplasia. Adv. Virol. 2016, 2016, 7310894. [CrossRef] [PubMed]

85. Trottier, H.; Mahmud, S.; Prado, J.C.; Sobrinho, J.S.; Costa, M.C.; Rohan, T.E.; Villa, L.L.; Franco, E.L. Type-specific duration of human papillomavirus infection: Implications for human papillomavirus screening and vaccination. J. Infect. Dis. 2008, 197, 1436-1447. [CrossRef] [PubMed]

86. Ralston Howe, E.; Li, Z.; McGlennen, R.C.; Hellerstedt, W.L.; Downs, L.S., Jr. Type-specific prevalence and persistence of human papillomavirus in women in the United States who are referred for typing as a component of cervical cancer screening. Am. J. Obstet. Gynecol. 2009, 200, 245.e1-245.e7. [CrossRef] [PubMed] 
87. Louvanto, K.; Rintala, M.A.; Syrjanen, K.J.; Grenman, S.E.; Syrjanen, S.M. Genotype-specific persistence of genital human papillomavirus (HPV) infections in women followed for 6 years in the Finnish Family HPV Study. J. Infect. Dis. 2010, 202, 436-444. [CrossRef]

88. Datta, P.; Bhatla, N.; Pandey, R.M.; Dar, L.; Patro, A.R.; Vasisht, S.; Kriplani, A.; Singh, N. Type-specific incidence and persistence of HPV infection among young women: A prospective study in North India. APJCP 2012, 13, 1019-1024. [CrossRef] [PubMed]

89. Vyshenska, D.; Lam, K.C.; Shulzhenko, N.; Morgun, A. Interplay between viruses and bacterial microbiota in cancer development. Semin. Immunol. 2017, 32, 14-24. [CrossRef] [PubMed]

90. Cherpes, T.L.; Meyn, L.A.; Krohn, M.A.; Lurie, J.G.; Hillier, S.L. Association between acquisition of herpes simplex virus type 2 in women and bacterial vaginosis. Clin. Infect. Dis. 2003, 37, 319-325. [CrossRef]

(C) 2019 by the authors. Licensee MDPI, Basel, Switzerland. This article is an open access article distributed under the terms and conditions of the Creative Commons Attribution (CC BY) license (http://creativecommons.org/licenses/by/4.0/). 